\title{
An Analysis of Solid Waste Disposal and Water Quality in Ugep Community, Cross River State, Nigeria
}

\author{
Analiza utylizacji odpadów stałych i jakości wody w gminie Ugep \\ w dystrykcie Cross River w Nigerii
}

\author{
Etim 0. Eteng ${ }^{1}$, Joseph S. Okputu ${ }^{2}$, Christopher Abetianbe ${ }^{2}$ \\ ${ }^{1}$ Department of Geography and Environment Sciences, University of Calabar, Nigeria \\ ${ }^{2}$ Department of Environmental Resource Management, University of Calabar, Nigeria \\ ORCID EOE https://orcid.org/0000-0001-8461-8761; JSO https://orcid.org/0000-0003-3281-161X; \\ CA https://orcid.org/0000-0002-2344-0629•okputujoseph@unical.edu.ng \\ Received: 23 May, 2021; Revised: 25 Sep, 2021; Accepted: 29 Sep, 2021
}

\begin{abstract}
The study carried out an analysis of solid waste disposal and its implication for water quality in the Ugep Community, located in Yakurr's Local Government Council of Cross River State, Nigeria. Findings revealed that there is a significant and adverse relationship between solid waste disposal methods and the quality of drinking water, along with domestic uses in the study area. Data was collected through the administration of 500 questionnaires, with family heads as points of primary contact. It was clear that the poor state of infrastructural development and the challenge of availability and access to requisite amenities, coupled with inefficient management of the few available resources, has further exposed inhabitants to health and welfare issues. Results indicate a significant relationship between the solid waste disposal (sanitation) method and water quality in the study area. Awareness creation on sanitary practices by health and related government agencies, as well as community members themselves, should be encouraged to participate, as it will ensure a sustainable and health-oriented waste disposal system, bearing in mind likely concerns for water quality. Contamination of water is more prevalent in stored water, especially at the point of usage, as compared to where water flows freely, and is used without being stored. If water quantity is massive, the challenge of low quality is easily resolved, as less sanitation problems would occur. Government and private organisations should implement and encourage economic empowerment initiatives, in order to improve the livelihoods of the residents of the community.
\end{abstract}

Keywords: solid waste, waste disposal, sustainable development, population, sanitary, resources, water quality

Streszczenie: W niniejszym opracowaniu dokonano analizy sposobów odprowadzania odpadów stałych i ich wpływu na jakość wody w obszarze gminy Ugep w Yakurr Local Government Council dystryktu Cross River w Nigerii. Wyniki ujawniły, że na badanym obszarze zachodzi istotny i niekorzystny związek między metodami usuwania odpadów stałych, a jakością wody pitnej oraz użytku domowego. Dane zostały zebrane na podstawie 500 kwestionariuszy wypełnionych przez głowy rodzin. Jednoznacznie wykazano, że zły stan infrastruktury oraz wyzwania związane z dostępem do niezbędnych udogodnień w połączeniu z nieefektywnym zarządzaniem nielicznymi istniejącymi zasobami w zakresie urządzeń sanitarnych narażają mieszkańców na problemy zdrowotne i socjalne. Wyniki przeprowadzonych badań wskazują, że istnieje istotny związek między metodą unieszkodliwiania odpadów stałych (odkażaniem), a jakością wody dostępnej w obszarze prowadzonych badań. Warunkiem stworzenia zrównoważonego i służącego zdrowiu systemu usuwania odpadów, przy jednoczesnej trosce o jakość wody jest zachęcanie przez służby medyczne i odpowiednie agencje rządowe, a także samych 
członków społeczności do wspólnego zaangażowania w proces podnoszenia świadomości na temat praktyk sanitarnych. Poziom zanieczyszczenia wody magazynowanej, zwłaszcza w miejscu jej użytkowania, jest znacznie wyższy niż wody rzecznej, wykorzystywanej bezpośrednio. W przypadku dostępności dużych zasobów wody, problem jej niskiej jakości można łatwo rozwiązać, ponieważ wiąże się to z mniejszą liczbą problemów sanitarnych. Zarówno organizacje rządowe jak i prywatne powinny wdrażać i wspierać inicjatywy na rzecz podniesienia poziomu ekonomicznego mieszkańców tej społeczności.

Słowa kluczowe: odpady stałe, utylizacja odpadów, zrównoważony rozwój, populacja, higiena, zasoby, jakość wody

\section{Introduction}

It is acknowledged and well appreciated that the challenges of managing the human environment have over the years elicited and attracted the attention and efforts of diverse stakeholders, ranging from governments, inter-governmental collaborations, international organisations, non-governmental organisations, concerned communities, as well as private individuals. This has led to enormous deliberations through meetings, workshops, seminars, research reports, and diverse fora, with most of them leading to policy formulations by way of treaties, protocols, as well as signing commitment brochures and memoranda of understanding, after serious and thought-provoking discussions. A key reflection can be seen in the various conferences on the Environment, from Stockholm in 1972, The Earth Summit, Rio in 1992, and the United Nations Conference on Environment and Development, 2015, just to mention a few.

A key area of concern, as an outcome of man's interaction with and exploitation of the environment, is the challenge of environmental sanitation, especially in the developing countries of the world like Nigeria, where population figures of over 200 million and continuing growth in urbanisation has witnessed changes in consumption patterns, with rising adverse effects on managing the environment.

Environmental sanitation, as defined by the Water Supply and Sanitation Collaborative Council (WSSCC 200o), is a conscious, coordinated, and deliberate intervention, aimed at reducing human contact with diseases, via the provision of hygienic environments for human habitation, with provisions that are determined to discontinue disease cycles. This includes the disposal or hygienic management of human and animal excreta, pollution, refuse collection, wastewater, storm water, the control of disease vectors, and the provision of washing facilities for personal and domestic hygiene.

Environmental sanitation includes, and is not limited to, attitude, facilities, and behaviours, which together, combine to constitute a "hygienic environment" (Diouf and Maiga 200o). Personal hygiene, household and environmental sanitation, in addition to safe drinking water, are essential for promoting good health. Where adequate attention is not paid to these matters, hundreds of thousands of children and adults can readily be affected or infected with diseases like dysentery, typhoid fever, jaundice, diarrhoea, and worm infestation. On the contrary, the occurrence of diseases is reduced, if the issues of personal hygiene, sanitation, and safe drinking water are properly addressed (Nwaiwu 2005). Pathogens in human excreta come in contact with food and water, and subsequently, enter into the human system, through the faecal-oral route. Frequent occurrence of this leads to outbreaks of diverse life-threatening diseases.

Although sanitation is the foundation of every development, a large number of the inhabitants of the developing world, do not have access to a standard and decent toilet facility that can be categorised as hygienic and infection free. The price to be paid for neglecting sanitation is to harvest diarrhoea, which thrives in unhygienic conditions, and alongside pneumonia, tagged 
the biggest child-killer on earth. It kills 2.2 million children each year, while others are left both physically and mentally retarded (Nwaiwu 2005). To achieve success in any low-cost sanitation programme, it is necessary to study the sociology, technology, and economics, of the people's solutions to their sanitation problems.

One of the major challenges of developing countries that has posed a prolonged health threat in the public health sector, has been the problem of improper disposal of human waste. Together with a failure to promote hygiene and bring about behavioural changes, with regard to human excreta disposals, it is the primary medium for the transmission of diseases like diarrhoea, typhoid, and cholera, affecting thousands of millions of people (WSSCC 200o). Human excreta and urine can transmit diseases. According to Fewtrell et al. (2005), "faeces are not only malodorous and aesthetically offensive, but may also contain pathogenic viruses, bacteria, lumps of protozoa and eggs of anthelmintic."

Statistics made available through the $\mathrm{Na}$ tional Population Census (2006) document on the distribution of regular household types of toilet facilities in Cross River State, indicated that out of 645,251 households in that State, only about 213,020 can be considered to have what could pass for a modern toilet facility, which is about 34 percent. On the other hand, a total of 432,231 households uses sanitary facilities (pit latrine, bucket/pan and nearby bush, gutters, beach and field) that are not good enough for man, the environment, and its components. This, therefore, confirms the reality that 66 percent of households in Cross River State make use of these poor sanitary facilities. This has posed a serious problem, such as the use of available space for faecal disposal, directly or indirectly, which may increase the faecal coliform count in the open water sources in the area (NPC 2006).

In Cross River State and Ugep Urban, in particular, the inadequacy of safe water and improved sanitation services is manifested in the prevalence of water and sanitation related diseases across various communities/villages (CRSG-OSG 2012). Diarrhoea, which results from poor sanitary /hygiene habits and consumption of water of poor quality, is the second main cause of infant mortality after malaria, and the third main cause of under-five mortality in Nigeria. This is, indeed, not sustainable, if the community is to key into national development programmes that are aimed at improving living standards amongst the Nigerian population.

According to Nwaiwu (2005), the social, behavioural, and institutional aspects of excreta disposal, has often been neglected in the past. The reaction of people to excreta disposal schemes or arrangement, depends upon both deep-rooted cultural values like religion, and ancestral beliefs, as well as other factors such as cost, convenience, and comfort. Each of these is capable of affecting the use or preference of the intervention. The human factor, though difficult to evaluate, because of problems that can arise due to conflicts with traditions, attitudes, and religious beliefs, apart from improved sanitation facilities and hygiene education efforts, needs to be carried out, alongside water supply schemes, for a lasting benefit to occur. In the absence of the above, faecal contamination will persist, especially where children's faeces are viewed as being harmless.

Inadequate public health and hygiene has been recognised to have had immediate and unswerving effects on the health of nations, communities, families, and individuals, as the case may be. Having the basic sanitary amenities in the community, is bound to improve economic productivity and human living conditions. According to Karn et al. (2011), "sanitation includes use of a latrine, observation of personal hygiene, a culture of maintaining clean surroundings, proper disposal of solid and liquid waste, and the sustenance of hygienic behaviour. The existence of toilet facilities is taken as an essential and basic indicator of health and sanitation worldwide”. Appropriate sanitary conditions or environments are necessary conditions, not only enhancing productive 
capacity of the active labour force, but also improving the overall health standards of the people, while contributing to a good life and general well-being (Dwivedi and Sharma 2007). Globally, about 5.3 percent of the overall mortality rate and 6.8 percent of overall disabilities have their origins in intolerable sanitary conditions, absence of safe drinking water as well as poor hygiene conditions. In Nepal, the limited and lack of access to sanitary amenities is very striking. According to Karn et al. (2011), about a total of 75 percent of the population is without access to basic sanitary facilities, one of the highest proportions in Asia.

In Nigeria, Fadare and Olawuni (2008) examined the impacts of household water supply on health. Using Osogbo as a case study, emphasis was placed on three areas with high population densities. The study findings revealed that a minor proportion of about 23.8 percent of the respondents from the densely populated areas, had fair accessibility to privately owned wells, boreholes, or public taps. On the other hand, the health effects included diarrhoea infections at 3.3 percent, stomach-ache at 20.2 percent, and typhoid illnesses -14.8 percent. This, by all indications, is a little above the other high-density areas, adopted by the study. Thus, the study established a prominent correlation between ill health and water supply in the densely populated areas of Osogbo, implying that the water source as well as distribution channels are contaminated.

According to WHO-UNICEF (2012), "human excreta have been identified as a major contributor in the transmission of many infectious diseases, including cholera, typhoid, infectious hepatitis, polio, cryptosporidiosis, and ascariasis. Thus, estimating that 2.1 million people die annually from diarrhoeal diseases, and that 10 percent of the population of the less-industrialised world suffer from parasitic worm infections, related to improper waste and excreta management. Poor sanitation, unhealthy hygiene practices and inadequate water supply are also related to the spread of other diseases, including tropical diseases, such as schistosomiasis (bilharziasis)". It is further established that parasitic diseases among humans include bilharziasis, which is the second most notorious disease in the subtropical and tropical parts of the world, measured by its influence on public concerns and socioeconomic impact. According to WHO-UNICEF (2013), "the disease is known to be prevalent in 74 developing countries, infecting more than 200 million people. Of these people, ten percent, which amounts to 20 million, suffer severe consequences from the disease. Trematode infections are caused by parasitic flatworms (also known as flukes) that infect both humans and animals. Infected individuals transmit trematode larvae in their faeces".

Improvements in water supply and sanitation services tend to lead to an up-take in people's health and the quality of their lives (Ishaku et al. 2011). It is on these grounds that Billig et al. (1999) established that "improvements in sanitation have been shown, consistently, to result in better health, as measured by fewer cases of diarrhoea, reductions in parasitic infections, increased child growth, and lower morbidity and mortality. The expected reductions in mortality can be substantial, particularly in areas with low levels of education". Anker R. and Knowles J.C. (1980) opined that although there will be better health situations if there are modest improvements in the provision of sanitary amenities, such as pit latrines, there are bound to be much greater health benefits if water closet toilets are provided. Bateman and Smith (1991) also corroborated this, when their study produced similar results. Hence, Huttly et al. (1997), "suggest that all efforts towards improving sanitation are worth undertaking, as they have community-level effects, as well as individual ones. It is commonly believed that the main health benefit from improved water supply occurs through better water quality, which reduces the ingestion of pathogens. Reviews, however, suggest that improvements 
in health associated with better water quality are smaller than those obtained through increases in the quantity of water, which allow for better personal and domestic hygiene practices, such as hand washing, food washing, and household cleaning". Over the years, the world has had to contend with sanitation related diseases with high tendencies of human transmission through contacts, notably SARS, Ebola in 2014, and Coronavirus, also called COVID-19 - which has been prevalent in the last three years.

\section{Study area}

Ugep Community is a town, and the administrative headquarters of Yakurr's Local Government of Cross River State. It is located in the Western part of Cross River State, and lies between longitude $08^{\circ} \mathrm{O}^{\prime} 4 \mathrm{O}^{\prime \prime}$ and $08^{\circ} 05^{\prime} 44^{\prime \prime} \mathrm{E}$, and latitude $05^{\circ} 47^{\prime} 30^{\prime \prime}$ and $05^{\circ} 48^{\prime} 33^{\prime \prime} \mathrm{N}$. The community is also approximately 98 kilometres from Calabar, the capital of Cross River State, Nigeria.

Ugep Urban lies within the lowland and scarp lands of Cross River State. The relief is gentle, aside from places where granite extrusions rise above the general level of the surface. The area rests on a height of 200 to 300 metres above the sea level, thus, limited incidence of flooding is observed. There are few or no clear statistics on the number of households with improved sanitary facilities, and by implication, general sanitation conditions are poor, as the incidence of open defecation and indiscriminate dumping of waste has been an ever-prevalent challenge in the Ugep Community, with concerns about human health, environmental pollution, and water quality.

\section{Materials and methods}

The study area, Ugep Urban was visited and a preliminary survey conducted, to get a feel of the perceived impressions, as well as expectations of the inhabitants on the issue of waste disposal and water quality in the designated geo-political wards that make up Ugep Urban. General questions were asked, and answers provided, on the state of waste disposal and water quality. The data sourced for the research ranged from Data on the waste disposal facilities in the study area. Field observations collaborated by respondents' answers, identified open dumping of refuse, open pit, disposal into water bodies - stream and ponds, in the bush on the way to farms, drainage or gutter, through burning and through dug pit and buried methods. Data on faecal coliform and fungi in the identified water sources was obtained from water samples collected and analysed in the laboratory. This is to determine water quality, especially in relationship

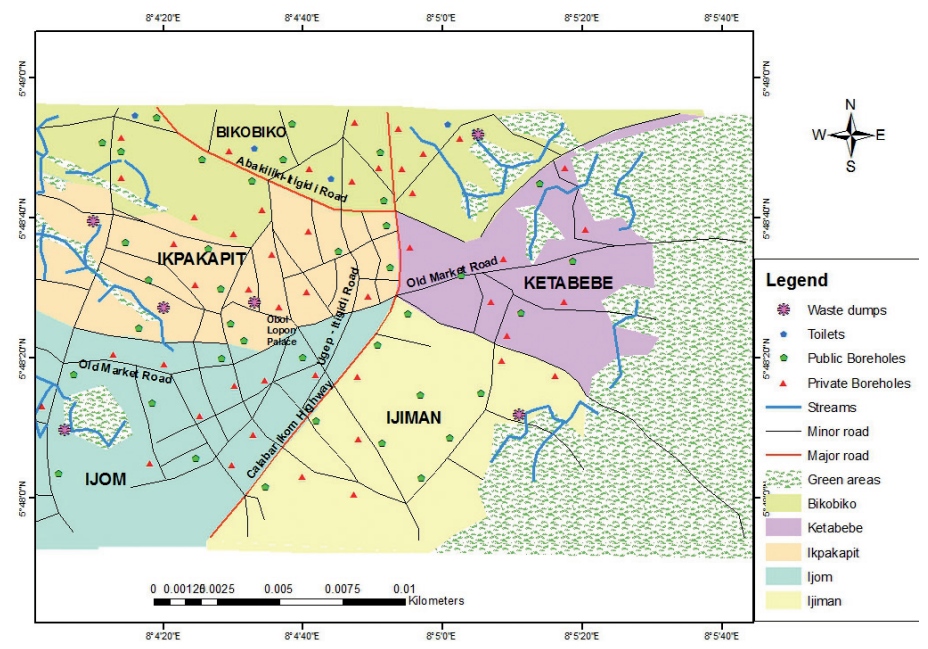

Figure 1. Location of the five wards in Ugep Urban study area 
to the effects on the sanitary services used by the inhabitants. These constitute primary data sources. Secondary sources of data were also obtained from the National Population Census, Cross River Independent Electoral Commission, and the Ministry of Lands and Surveys. Other notable secondary sources included conference proceedings, journals on water and sanitation, magazines, unpublished dissertations and theses, textbooks, maps, photographs, and gazettes available from libraries and through the internet. Focus Group Discussions were also held in the course of the surveillance survey: civil servants, and artisans, as well as farmers, were interviewed and relevant data also collected.

\section{Procedure for data collection}

The major source of data collection for this research was conducted through the administration of structured questionnaires. The questionnaire was drawn up by the researcher, and reviewed for correctness, to suit the objectives of the research. The questions covered aspects of waste disposal methods, water sources, and demographic information from respondents, such as: age, sex, marital status, educational qualifications, and occupation, as well as income levels. Information on the state or level of waste disposal methods, and their impressions on water quality, were elicited from respondents. The population of this study was made up of all adults, 18 years and above, in Ugep Urban. According to the National Population Census 2006, this population stands at 116,092. Due to non-existent data on the population figures for Ugep Urban, the only source available was for the entire Yakurr local government, without figures, for each of the thirteen geo-political wards. The Cross River State Independent Electoral Commission was therefore, approached, and the figures captured in the Voters Register were used for the research, bearing in mind that only persons of 18 years and above, i.e., the youth and adult populations who are naturally expected to be aware of events around them, were used as respondents.

In order to select the sample of the study, the Taro Yamane (1967) formula of sample size determination was employed, to determine the sample size for the study. The formula is given as:

$$
n=\frac{N}{1+N \times(e)^{2}}
$$

where $\mathrm{n}=$ sample size required, $\mathrm{N}=$ total number of population, e = level of significance at 0.05 .

Given the population of 116,092, our sample size becomes as follows:

$$
\frac{116092}{1+\left(116092 \times 0.05^{2}\right)}=400
$$

This approximately gives a sample size of 400. The researcher decided to add 100 respondents, giving a total of 500 respondents selected and used for the study (Table 1).

\section{Data analysis hypothesis}

Table 2, which shows how wastes generated across the various sampled areas depicted that the most preferred option for disposing of wastes was the open dump method,

Table 1. Population and sample size distribution across the five wards in Ugep Urban

\begin{tabular}{lcc}
\hline Wards & Population & Sample size \\
\hline Bikobiko & 20,782 & 90 \\
\hline Ketabebe & 24,926 & 107 \\
\hline Ijiman & 18,672 & 80 \\
\hline Ijom & 27,893 & 120 \\
\hline Ikpakapit & 23,819 & 103 \\
\hline Total & 116,092 & 500 \\
\hline
\end{tabular}




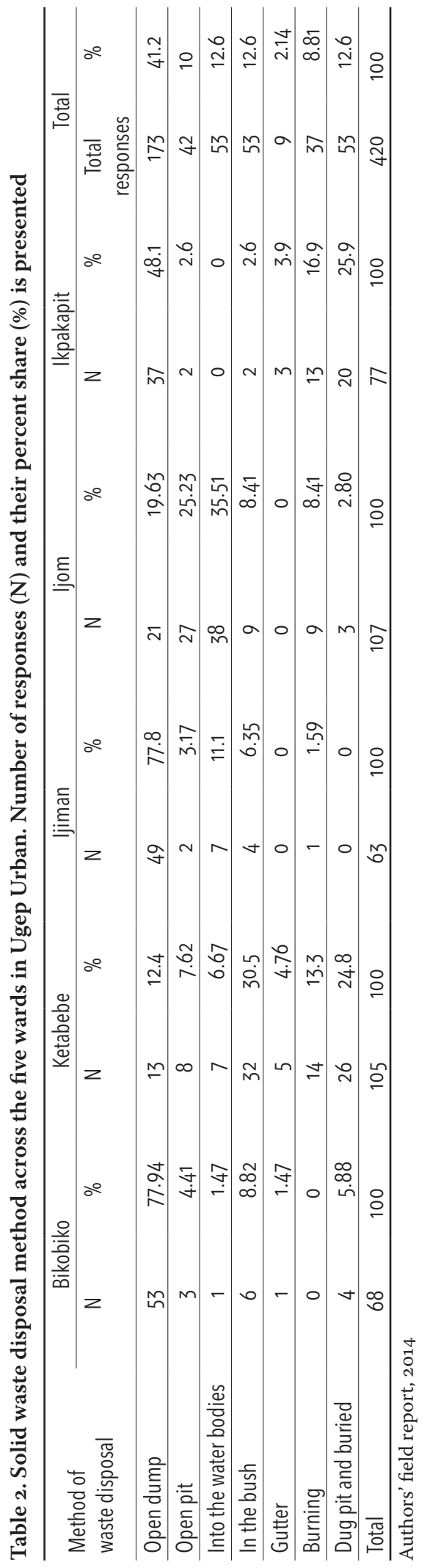


as seen in Bikobiko with $77.9 \%$, Ijiman with $77.8 \%$, and Ikpakapit with $48.1 \%$. On the other hand, it was also noticed that in Ketabebe, the generated waste was thrown into the bush, with the option ranking highest at $30.5 \%$. However, the respondents in Ijom said that they dispose of their waste into water bodies, as the option had a value of $35.5 \%$.

In general, it was observed that the wastes generated in the area were openly dumped with a value of $41.2 \%$. On the other hand, it was also seen that the inhabitants of the area also indulged in dumping waste into water bodies, in the bush, and also buried in dug pits, as all of these options had values of $12.6 \%$ respectively. From this study, one could observe that a lot needs to be done regarding waste disposal, as the open dumping method, which is predominant in the area does not meet the aspirations of the Sustainable Development Goals' and Millennium Development Goals' targets, concerning basic and hygienic sanitation.

In the Ugep Urban, the reason for the high incidence of open dumping of refuse across the five wards, has been attributed to the close proximity of a waste dump site, attitude, and lack of waste baskets in homes (personal interview). Although there is a central body (Ugep Urban Development Authority) that is responsible for refuse disposal, it still lacks the technical knowhow and requisite infrastructure to curtail the incidences. In other cases, especially farmers, prefer carrying their waste on their farm basins, and either dump on their farmlands, or by the roadside leading to their farms. For some, it is a means to add manure to the soil. This method has been in practice right from the beginning of time, and it has helped their crops to grow well, irrespective of the level of soil degradation. There is a need for education on the proper and best way to dispose of refuse, as well as on how to recycle waste for proper farm management.

\section{Results and discussion}

Two ANOVA analyses (Tables 3 and 4) were conducted to verify the following hypotheses:

$\mathbf{H}_{\mathbf{o}}$ : There is no significant relationship between solid waste disposal (sanitation) method and water quality in the study area.

$\mathrm{H}_{\mathrm{i}}$ : There is a significant relationship between solid waste disposal (sanitation) method and water quality in the study area.

Table 3. Analysis of variance (ANOVA) waste disposal methods

\begin{tabular}{lcccc}
\hline Source of Variance & Df & SS & MS & F-ratio \\
\hline Wards & 4 & 1532 & 28.3 & - \\
\hline Methods of Waste Disposal & 6 & 898.2 & 145.75 & 0.57 \\
\hline Error & 24 & 6154 & 256.4 & - \\
\hline Total & 34 & 7205.7 & - & - \\
\hline
\end{tabular}

Table 4. Analysis of variance (ANOVA) water quality

\begin{tabular}{lcccc}
\hline Source of Variance & Df & SS & MS & F-ratio \\
\hline Wards & 4 & 3871.2 & 967.8 & - \\
\hline Water Sources & 9 & 1549 & 172.1 & 1.13 \\
\hline Error & 34 & 5448.8 & 151.36 & - \\
\hline Total & 47 & 1086.9 & - & - \\
\hline
\end{tabular}




\section{Decision}

Since the F-ratio of solid waste disposal 0.57 is less than the F-ratio of water sources given as 1.13, the $\mathrm{H}_{\mathrm{o}}$ is rejected and the $\mathrm{H}_{\mathrm{i}}$ accepted. Thus, there is a significant and adverse relationship between solid waste disposal methods and quality of water for drinking and domestic uses in the study area.

\section{Conclusion}

In Ugep Urban, access to quality solid waste disposal facilities is hampered due to poverty, as there exists little or no savings left to enable them to improve their position, in line with modern standards. Also, water available for an inhabitant's usage, especially for drinking, is poor in quality, most of which comes from streams. This is consequent upon the excessive contamination of the water bodies through waste dumping, faecal deposition, and contamination from bacteria and physio-chemical components in the environment. Again, despite the increasing level of urban development, the sanitation level is generally poor in the area.

General conclusions that could be made, concerning access to water and sanitation, include: a) improvements in health associated with better water quality, are smaller than those obtained through increases in the quantity of water, which allow for better personal and domestic hygiene practices; $b$ ) contamination of water is more prevalent in stored water, especially at the point of usage, as compared to where water flows freely, and is used without being stored. If water quantity is massive, the challenge of low quality is easily resolved, as less sanitation problems would occur; c) populations that use more water have better health than groups that use less water. As the distance from the location of water sources to the household increases, the less the quantity of water the inhabitants can fetch, as compared to the situation where the water source is located in their dwelling place, or within their compound; d) the government should undertake the regulation, legislation, and enforcement of waste disposal laws at the ward levels, and partner with private organisations to provide dump sites and conversion areas, where waste can be converted to more useful products. The communities can also be engaged to design and implement costeffective solid waste result-oriented plans, which will include recycling. In addition to these, the local planning regulatory agencies should ensure that only approved building plans and designs, which meet the relevant sanitary standards, are used for building construction in the various communities.

Author Contributions: Conceptualization, E.O.E. and J.S.O.; Methodology, E.O.E.; Validation, E.O.E., J.S.O. and C.A.; Formal Analysis, E.O.E.; Investigation, E.O.E.; Writing - Original Draft Preparation, E.O.E.; Writing - Review \& Editing, E.O.E., J.S.O. and C.A.; Visualization, E.O.E.; Supervision, E.O.E. and J.S.O.. All authors have read and agreed to the published version of the manuscript.

Funding: This research received no external funding. Institutional Review Board Statement: Not applicable.

Conflicts of Interest: The authors declare no conflict of interest.

Acknowledgments: The authors want to acknowledge Ntite Orji Kalu for the overall editing and organisation of the paper.

\section{References}

Anker Richard, and James C. Knowles. 1980.

"An empirical analysis of morbidity differentials in Kenya at the macro and micro levels." Economics, development and cultural change 29(1): 165-185.

Bateman, O. Massee, and Shelley Smith. 1991.

"A Comparison of The Health Effects of Water Supply and Sanitation In Urban and Rural Guatemala." WASH Field Report 352.

Billig, Patricia, Diane Bendahmane, and Anne Swindale. 1999. "Water and Sanitation Indicators: Measurement Guide. Food and Nutrition Technical Assistance Project." Academy for Educational Development.

Cross River State Government-Office of Statistician General (CRSG-OSG). 2012. Economic and 
Planning Report. Cross River State Government, Nigeria.

Diouf El hadj Moustapha, and Hamidou Maiga. 2020. "Rural Water Supply, Hygiene Education and Sanitation: An Integrated Approach in Mali." Global Environmental Sanitation Initiatives -Second World Water Forum and Ministerial Conference. The Hague 17-22 March, 2000.

Dwivedi, Pankaj, and A. N. Sharma. 2007. "A Study on Environmental Sanitation, Sanitary Habits and Personal Hygiene Among the Baigas of Samnapur Block of Dindori District, Madhya Pradesh." Journal of Human Ecology 22(1): 7-10. DOI: https:// doi.org/10.1080/09709274.2007.11905991.

Fadare, S. O., and Peter Olawuni. 2008. "Domestic Water Supply and Health of Households in The Three Residential Densities in Osogbo, Osun State, Nigeria." Ethiopian Journal of Environmental Studies and Management 1(2): 35-43.

Fewtrell, Lorna, Rachel Kaufmann, David Kay, Wayne Enanoria, Laurence Haller, and John Colford Jr. 2005. "Water, sanitation, and hygiene interventions to reduce diarrhoea in less developed countries: a systematic review and meta-analysis." The Lancet Infectious Diseases 5(1): 42-52.

Huttly, Sharron, Saul S. Morris, and V. Pisani. 1997. "Prevention of Diarrhoea in Young Children in Developing Countries." Bulletin of the World Health Organization 75(2): 163-174.

Ishaku, Hassan, Majid Rafee, Peters Ajayi, and Ali Haruna. 2011. "Water Supply Dilemma in Nigerian Rural Communities: Looking Towards the Sky for An Answer." Journal of Water Resource and Protection 3(8): 598-606. DOI: https://doi. org/10.4236/jwarp.2011.38069.

Karn Rajiv, Buna Bhandari, and Nilambar Jha. 2011. "A Study on Personal Hygiene and Sanitary Practices in A Rural Village of Mornag District of Nepal." Journal of Nobel Medical College 1(2): 39-44.

National Population Commission (NPC). 2006. "Population and Housing Census of The Federal Republic of Nigeria." National and State Population and Housing Priority Table Volume 1. National Population Commission, Nigeria.

Nwaiwu, Nkeiruka. 2005. A Knowledge, Attitude, and Practice (KAP) Study of Water Supply, Sanitation and Hygiene Practices in Rural Areas of Borno State, Nigeria. (Masters Dissertation). Ahmadu Bello University, Zaria, Nigeria.

Water Supply and Sanitation Collaborative Council (WSSCC). 2000. "Campaign Sects Improved Health and Well-being for Nearly 3 billion people". In Second World Water Forum and Ministerial Conference, 17-22 March 2000, The Hague: from vision to action: final report. The Hague: Netherlands Ministry of Foreign Affairs.

WHO-UNICEF. 2012. Progress on Drinking Water and Sanitation:2012 update. New York: UNICEF. WHO-UNICEF. 2013. Progress on Sanitation and Drinking Water. 2013 update. Albany: World Health Organisation.

Yamane, Taro. 1967. Statistics: An Introductory Analysis. New York: Harper and Row. 